\title{
SEASONAL SURFACE-VELOCITY VARIATIONS ON A SUB-POLAR GLACIER IN WEST GREENLAND
}

\author{
By JøRN-OLE ANDREASEN
}

(Geological Institute, University of Aarhus, Langelandsgade bygn. 521, 8000 Århus C, Denmark)

Abstract. Eight stakes situated in the ablation and the accumulation areas of a sub-polar glacier in West Greenland were surveyed at intervals of 10 days during the summers of 1982 and 1983. The horizontal velocity in both the ablation and the accumulation areas increased distinctly during the short summer season. This indicates that melt water reaches the bed and that the glacier is sliding. It is proposed that melt water produced in the ablation area is forced up-glacier through a subglacial water system. The vertical displacement of stakes showed variations indicating an apparent uplift of the glacier during the summer. However, this is interpreted as the result of seasonal variation in atmospheric refraction.

RÉsumé. Variations saisonnières des vitesses superficialles sur un glacier sub-polaire $d u$ Groenland occidental. Huit balises implantées dans les zones d'accumulation et d'ablation d'un glacier de type sub-polaire de l'ouest du Groenland ont été relevées tous les dix jours pendant les étés 1982 et 1983. L'augmentation estivale de la composante horizontale de la vitesse dans les deux zones montre que l'eau de fusion atteint le lit et que le glacier dérape. On suggère qu'un réseau sous glaciaire

\section{INTRODUCTION}

Seasonal variations in surface velocity of glaciers, showing higher velocities during the summer period, have been known for more than a century. Variations of surface velocity in temperate glaciers have been noted by numerous observers, e.g. Meier (1960), Paterson (1964), Hodge (1974), Iken ([1978]), and Iken and others (1983). Few investigations have been made on sub-polar glaciers, e.g. Battle (1951), Müller and Iken (1973), and Brzozowski and Hooke (1981). (The term "sub-polar" is used to denote that the temperature over parts of the glacier is negative, even in summer, down to a certain depth, i.e. it does not exclude a warm base.)

Seasonal variations in glacier velocity have two possible explanations. They may result from changes in ice thickness produced by the seasonal variation of accumulation and ablation, or they may be caused by the "lubrication" effect of melt water at the glacier bed (Paterson, 1981). It is usually assumed that the variations in velocity are primarily a result of changes in sliding brought about by changes in the subglacial water pressure. Consequently, measurements of glacier-velocity variation are a means of providing information about the glacial drainage system.

In recent years not only horizontal velocity variations but also the vertical movement have been analyzed (Iken, [1978]; Hooke and others, 1983; Iken and others, 1983). The discovery of vertical velocity variations has led to the development of a new theory of basal sliding (Iken, 1981) and to calculations of glacier-bed geometry (Hooke and others, 1983; Iken and others, 1983). However, some apparent short-term velocity variations may be due to the effect of variations in atmospheric refraction (Andreasen, 1985).

As part of a glacier-hydrological investigation at a subpolar glacier ("Kitdlerssuaq glacier") at Tasersiaq in West permet à l'eau de fusion produite dans la zone d'ablation de remonter vers l'amont. Le mouvement vertical des balises indique un exhaussement de la surface du glacier en été mais on attribue plutôt ce phénomène à des variations saisonnières de le réfraction atmosphérique.

Zusammenfassung. Jahreszeitliche Änderungen der Oberflächengeschwindigkeit auf einem subpolaren Gletscher in West-Grönland. Während der sommer von 1982 und 1983 wurden 8 Pegel im Albations- und Akkumulationsgebiet eines subpolaren Gletschers in West-Grönland in 10-tägigen Intervallen eingemessen. Sowohl in der Ablations- wie in der Akkumulationszone nahm die Horizontalgeschwindigkeit während der kurzen Sommerperiode merklich zu. Dies deutet darauf hin, dass Schmelzwasser bis zum Felsbett durchdringt und dass der Gletscher gleitet. Es wird vermutet, dass Schmelzwasser aus dem Ablationsgebiet gletscheraufwărts durch ein subglaziales Stromsystem gedrăngt wird. Die vertikale Versetzung der Pegel zeigte Verănderungen, die auf eine scheinbare Hebung des Gletschers wăhrend des Sommers hindeuten. Doch muss diese Erscheinung vermutlich als Wirkung der jahreszeitlichen Änderung in der atmosphärischen Refraktion gedeutet werden.

Greenland, measurements of glacier-velocity variations were carried out. An investigation of short-term (12-24 h) glacier-velocity variations on "Kitdlerssuaq glacier" in 1982 showed that both horizontal and vertical variations were probably the result of variations in atmospheric refraction (Andreasen, 1985); consequently, only weekly variations were determined in 1983.

\section{LOCATION}

"Kitdlerssuaq glacier" is an outlet glacier from a local ice cap ("Amitsulóq ice cap") situated about $50 \mathrm{~km}$ east of Sukkertoppen Iskappe (Fig. 1). "Kitdlerssuaq glacier" covers an area of approximately $25 \mathrm{~km}^{2}$. The accumulation area extends down to approximately $1350 \mathrm{~m}$, from where the glacier drains eastward down to $780 \mathrm{~m}$ (Fig. 2). The accumulation area is partly divided by a nunatak. The transient snow line was at about $1050 \mathrm{~m}$ at the end of the 1982 ablation season, whereas the glacier was completely snow-covered during the summer of 1983. "Kitdlerssuaq glacier" advanced approximately $10 \mathrm{~m}$ in 1982-83. The glacier is coded No. 1 DG 16166 in the West Greenland. Inventory and is located at lat. $66^{\circ} 07^{\prime} \mathrm{N}$., long. $50^{\circ} 10^{\prime} \mathrm{W}$.

\section{METHODS}

The surface velocity and the direction of movement of the stakes in 1982-83 were determined by intersection from fixed points ( $A_{e}, A_{s}, B_{s}$, and N; Fig. 2) on bedrock or on stable moraine along the periphery of the glacier. The seasonal variation in surface velocity was determined by surveying the angle between a fixed point and the stake over a period of time. Movements were calculated from angular displacements and the distance from the instrument 


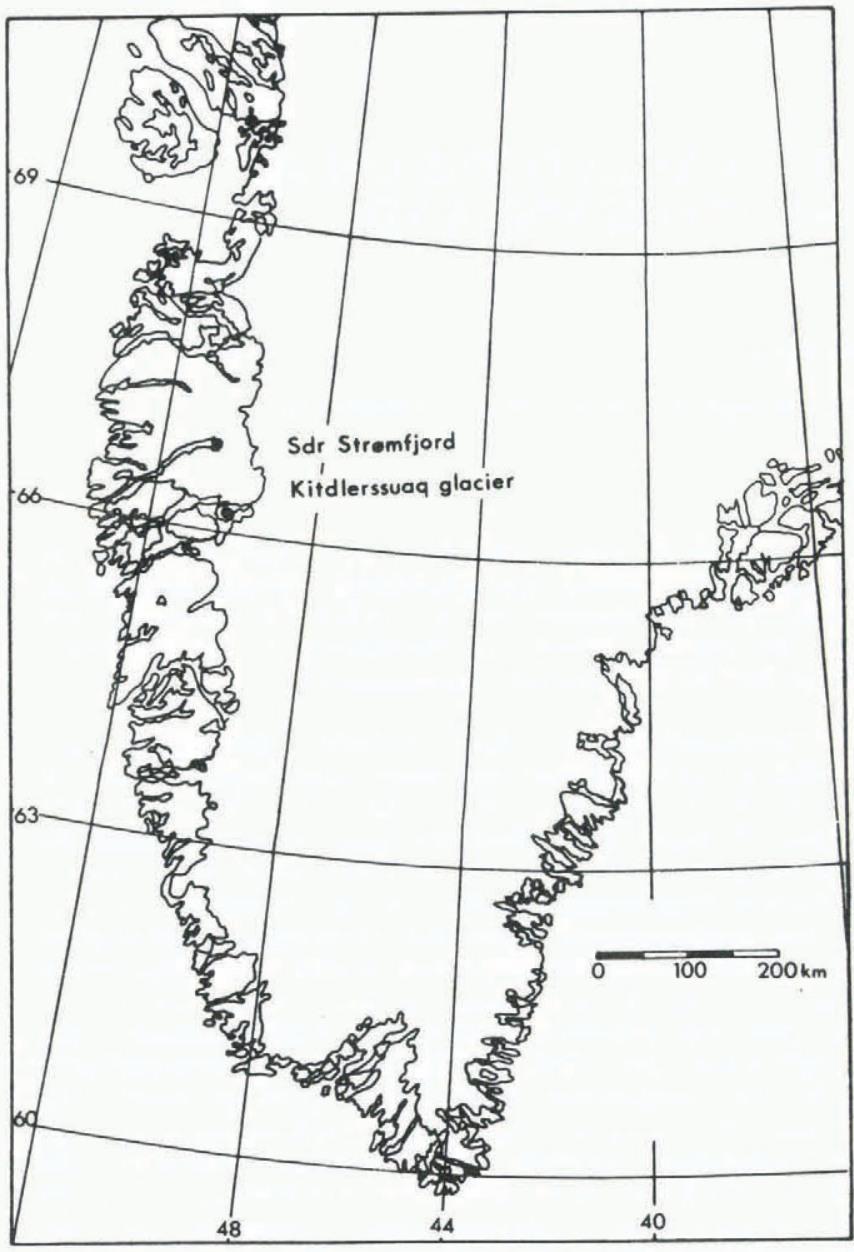

Fig. 1. Sketch map of West Greenland showing the location of "Kitdlerssuaq glacier".

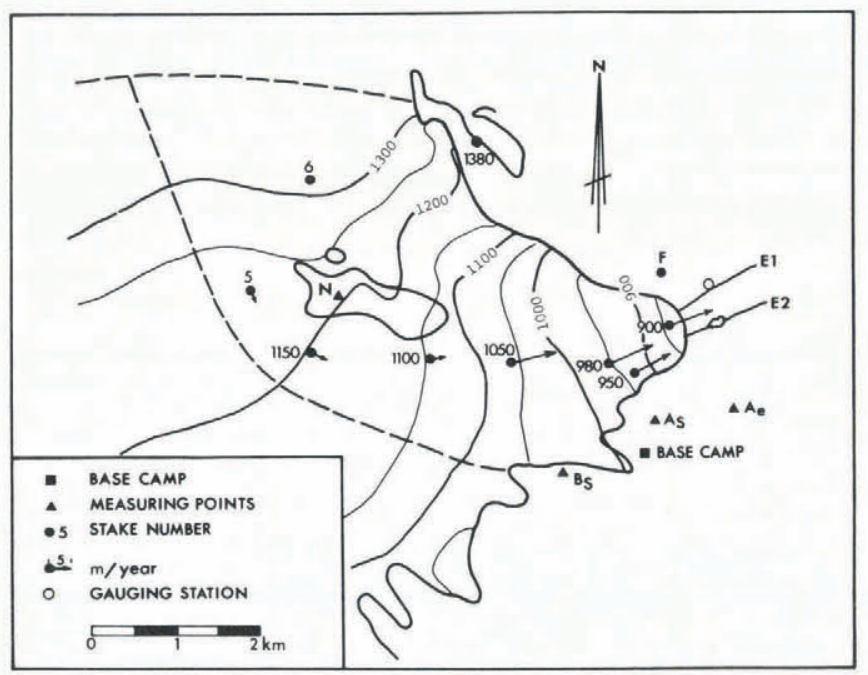

Fig. 2. "Kitdlerssuaq glacier" with stake positions and velocity vectors. The dashed line indicates the approximate boundary of the glacier.

to the stake by using the direction of movement determined in 1982-83.

Angle measurements were made with a Carl Zeiss Jena Theo 010A theodolite, with readings to $0.0002^{\mathrm{g}}$. The theodolite has automatic vertical index stabilization. The angle measurements were determined using a complete round expanded after transit of the theodolite to a double complete round.
The standard deviation of angle measurements was determined using directions of sight to two fixed points. One point was located on the same side, the other point on the opposite side of the glacier $\left(\mathrm{B}_{\mathrm{S}}\right.$ and $\mathrm{F}$, respectively) relative to the survey point $A_{s}$. At a given time, the accuracy of the vertical angle from $A_{s}$ to $F$ was determined as $\pm 0.0003^{\mathrm{g}}(n=30)$. When readings to fixed points were taken during the summer, at the same time as readings to stakes, the accuracy of vertical angles was determined as $\pm 0.0008^{\mathrm{g}}(n=33)$ and $\pm 0.0015 \mathrm{~g}(n=26)$ for the fixed points on the same side $\left(B_{S}\right)$ and on the opposite side $(F)$ of the glacier, respectively. The discrepancy between the accuracy at a given time and the accuracy during the summer is interpreted as a result of changes in refraction during the longer period, and the greater standard deviation for the measurements to $F$ as a result of greater refraction over snow and ice surfaces (Andreasen, 1985). The standard deviation of horizontal angle measurements was determined using the fixed angle between the two points $B_{S}$ and $F$. Readings were taken during the summer, at the same time as readings to stakes. The accuracy of horizontal angles was in this way determined as $\pm 0.011^{\mathrm{g}}(n=25)$.

\section{RESULTS AND DISCUSSION}

\section{Horizontal velocity}

Stake positions and the direction and magnitude of ice velocity are shown in Figure 2. In Figure 3, seasonal horizontal velocity variations in 1982 and 1983 are presented together with the daily mean temperature measured at the base camp and the discharge of the main melt-water outlet (E1). Ice and snow at the gauging station at the beginning of the melt season prevented reliable discharge measurements in June. A reasonable relation between daily ablation and temperature exists at Qamanârssup sermia, about $185 \mathrm{~km}$ south of "Kitdlerssuaq glacier" (Braithwaite and Olesen, 1982). An indication of daily ablation at "Kitdlerssuaq glacier" is given by the daily mean temperature at the base camp.

At stakes 950 and 980 , ice velocity decreased by an order of $30-40 \%$ from July to September 1982. In June, temperatures were rather high, and the ice velocity may have been higher in June than in July, but no velocity measurements were made during that month. Apparently, the decrease in velocity was interrupted by a small increase in the period 24-31 July.

At stakes 1050 and 1100 , situated in the lower part of the accumulation area, the glacier velocity reached a maximum 3 weeks later, in the period 24 July-6 August 1982, immediately followed by a marked decrease in ice velocity. At stake 1100, maximum velocity was more than twice the annual velocity.

Although the glacier was completely snow-covered during the summer season of 1983, and both temperatures and discharge were much lower in 1983 than in 1982, marked velocity variations were observed. In the middle of July a distinct increase in velocity was found at stakes 900 , $950,980,1050$, and 1100. Two weeks later, the velocity decreased markedly at stakes 900,950 , and 980 , whereas the velocity at stakes 1050 and 1100 remained high for another week. At stakes 1150 and 5, the velocity increased through July to a maximum in the period 25 July-2 August.

Seasonal variations in glacier velocity in the ablation area of "Kitdlerssuaq glacier" (stakes 900, 950, and 980) are as expected, because they agree with results of earlier investigations on sub-polar glaciers. On White Glacier, Axel Heiberg Island in the Canadian Arctic Archipelago, Müller and Iken (1973) found that the summer velocities were about $10-60 \%$ greater than the winter velocities and, on Storglaciären in northern Sweden, Hooke and others (1983) found that the maximum summer velocity was $40 \%$ greater than the mean winter velocity. At both White Glacier (Iken, [1978]) and Storglaciären (Hooke and others, 1983), negative temperatures were measured in the ablation area but the ice was temperate near the bottom, and velocity variations were explained as variations in glacier sliding.

In Greenland, too, glacier-velocity variations have been measured in the ablation area. In West Greenland, a century ago, Steenstrup (1883) investigated seasonal velocity 

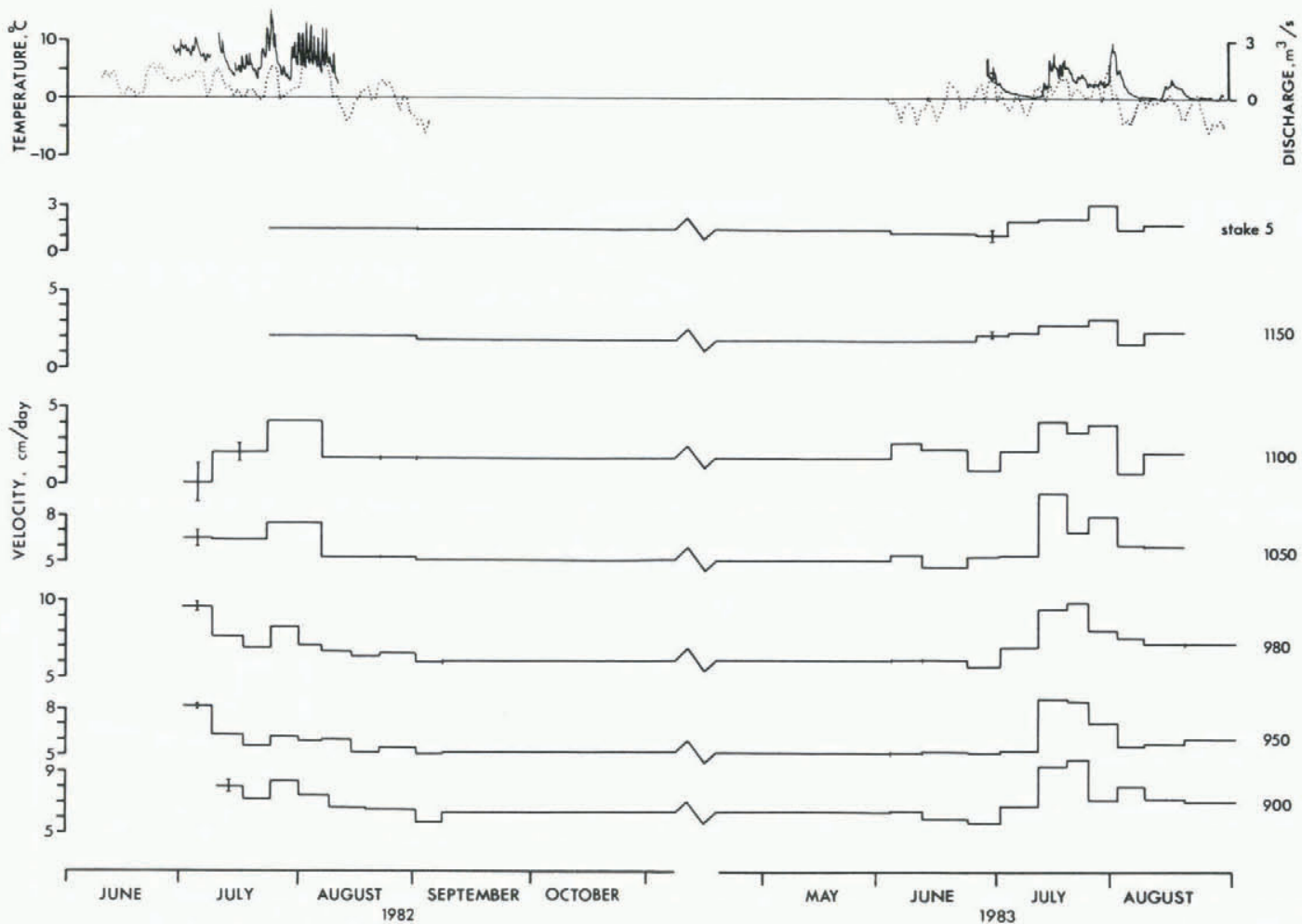

Fig. 3. Seasonal velocity variation on "Kitdlerssuaq glacier", together with daily mean temperature (dotted line) and discharge. Note that the time-scale is interrupted between summer seasons.

variations on glaciers on Nugssuaq and he concluded that "the velocity ... decreases through winter and spring". Seasonal velocity variations have been reported from Nordbogletscher (Clement, 1983[b]) and from Qamanarssap sermia (Andreasen, 1982). In East Greenland, Paterson (1961) measured decreasing velocity on Sefstrøms Gletscher through August and, on Bersærkerbraæ, Friese-Greene and Pert (1965) found a correlation between the rate of flow and rate of ablation during the period 7 July-25 August.

Temperature measurements are not available from the ablation areas of the above-mentioned glaciers or from "Kitdlerssuaq glacier". However, previous investigations at nearby glaciers suggest that ice temperatures in the ablation area of "Kitdlerssuaq glacier" are below zero. At Isua, close to the margin of the inland ice and approximately $90 \mathrm{~km}$ south of "Kitdlerssuaq glacier", Colbeck and Gow (1974) found negative temperatures in the whole ice body, but they extrapolated the temperature at the ice/rock interface to be $0^{\circ} \mathrm{C}$. In the ablation area of Sukkertoppen Iskappe, 50-100 km to the west of "Kitdlerssuaq glacier", negative temperatures have been measured (Henry and White, 1964; Hooke and Koci, 1978).

It seems safe to conclude that the temperature of the ice in the ablation area of "Kitdlerssuaq glacier" is negative down to a certain depth. This is supported by the fact that all stakes on "Kitdlerssuaq glacier" were frozen into the ice throughout the year.

In 1982, a maximum in glacier velocity in the ablation area occurred at the beginning of July. The entire glacier was snow-covered with large slush areas and the glacierdrainage system was poorly developed. This can be seen from the discharge curve; although discharge was high, diurnal amplitude was small. Probably, large amounts of water went into storage in and below the lower part of the glacier, causing high subglacial water pressure and subsequent high sliding velocity. As the drainage system developed, the temporarily stored water gradually drained and the ice velocity decreased.

In 1983, temperatures were lower than in 1982 and the maximum in glacier velocity in the ablation area was delayed a couple of weeks compared with 1982. In both 1982 and 1983, a maximum in glacier velocity occurred while the glacier was still snow-covered.
Velocity variations in the ablation area were as expected, whereas velocity variations measured in the accumulation area proper are quite surprising. In the accumulation area, variation in glacier velocity is normally either not significant or shows a maximum velocity in late winter, and it is then explained as the result of changes in ice thickness. At Hintereisferner in the Alps, Schimpp (1958) measured the maximum velocity in the firn area in late April/early May, whereas Brecher (1966) found no significant differences from the mean seasonal surface velocity in the accumulation area of Kaskawulsh Glacier, Yukon Territory, Canada.

In 1982, the maximum surface velocity occurred one month later at stake 1050 (at the equilibrium line) and at stake 1100 in the ablation area. In 1983, a distinct rise in surface velocity at stakes 1050 and 1100 occurred at the same time as at the lower situated stakes, but the velocity remained high. At stakes 1150 and 5 , at higher levels in the accumulation area, the maximum was reached in late July-early August.

As the maximum in glacier velocity was observed in late July, it is not plausible to explain it by winter accumulation. It is more likely caused by subglacial storage of melt water at the glacier bed beneath the accumulation area.

As noted, the increase in velocity in the ablation area during summer is probably explained by the variation in sliding velocity. This in turn implies that the basal ice is at the melting point and that melt water can penetrate to the bed, even though the ice is below the melting point down to a certain depth. Cold ice must be impermeable on the intergranular scale. Paterson (1981) mentioned that water might reach the glacier bed by penetration from the sides, if they are not frozen to the bed, whereas Iken (1972) argued that moulins on White Glacier are connected to the subglacial drainage system. However, water at the bed of sub-polar glaciers may also originate from the accumulation area. In the accumulation area, melt water percolates down through the firn until it reaches layers with a negative temperature, where it refreezes and releases latent heat. When the ablation is sufficiently great, this causes the winter cold wave to disappear. When the whole ice mass is at the pressure-melting point, melt water from the accumu- 

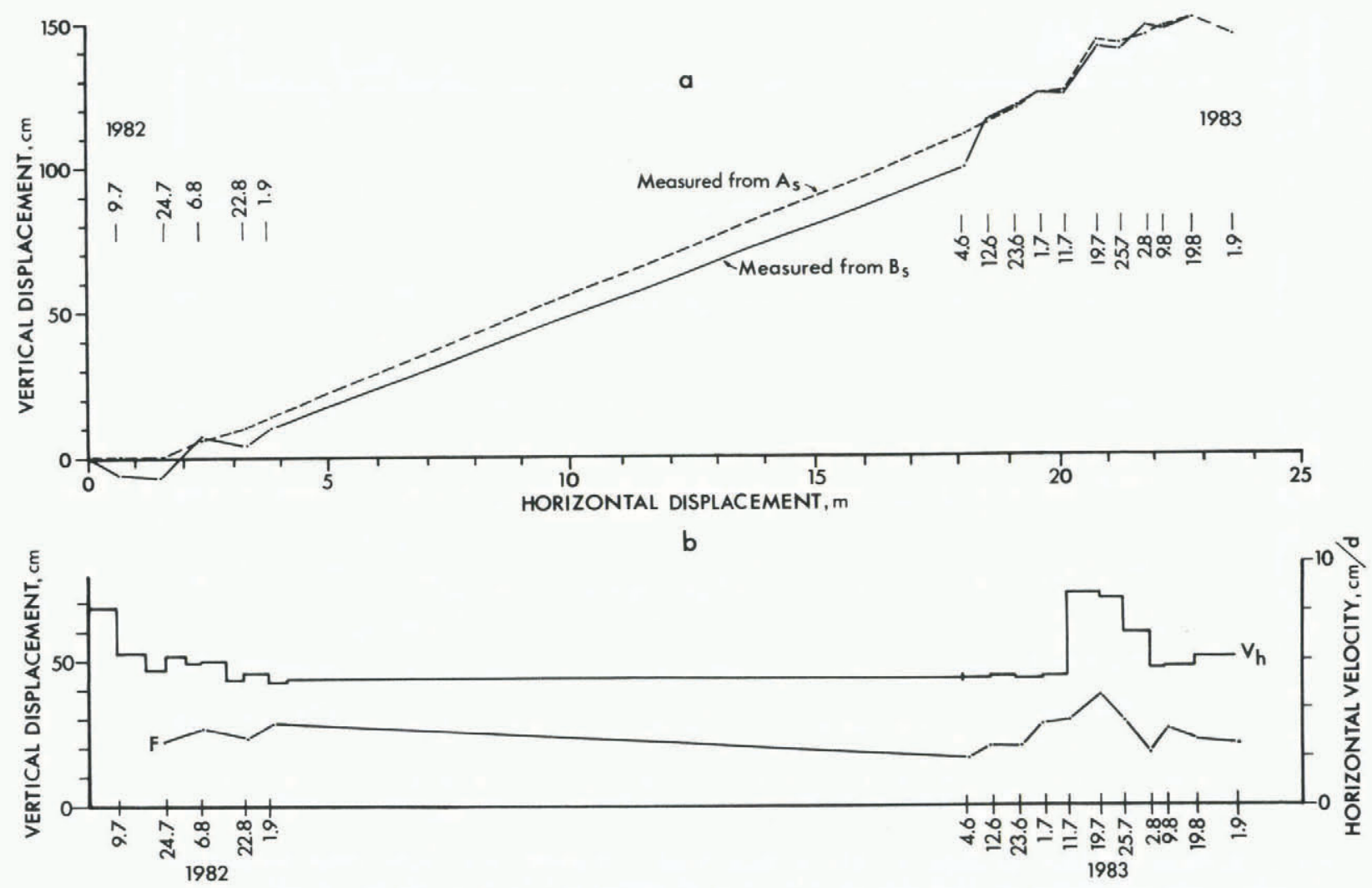

Fig. 4. Vertical displacement of stake 950 as measured from stations $A_{s}$ and $B_{s}$, respectively, and the apparent displacement of the fixed point $F$ as measured from $A_{s}$ at the same time. Horizontal velocity $\left(V_{h}\right)$ of stake 950 versus horizontal displacement is shown as well.

lation area may percolate down to the glacier bed. At still lower elevations, where ice layers make the firn impermeable, the temperature stays below the freezing point and remains so over the lower part of the accumulation area and over the entire ablation area.

This type of temperature condition, with low temperatures in the higher parts of the accumulation area, temperatures at the melting point in parts of the accumulation area and negative temperatures in the ablation area, is typical of sub-polar regions (Schytt, 1969).

As regards "Kitdlerssuaq glacier", most melt water in the ablation area (1982) disappeared into two moulins and small surface cracks, and only minor amounts of water discharged superficially. In the accumulation area, the temperature was measured in 1983 at stake 5 (1200 m a.s.1.) down to a depth of $10 \mathrm{~m}$, and here the temperature was negative (below $-3^{\circ} \mathrm{C}$ ) throughout the summer. The temperature may have been higher in lower parts of the accumulation area but all stakes were frozen in the firn throughout the summer, and this indicates that the winter cold wave was not eliminated. Temperatures at stake 5 are only available from the cold 1983 summer, but also in 1982 all stakes were frozen in the firn.

Observations during Project Mint Julep (lat. $66^{\circ} 17^{\prime} \mathrm{N}$., long. $47^{\circ} 46^{\prime} \mathrm{W}$.) showed that the net ablation above the firn limit was nearly zero, as percolating melt water refroze in the firn layers (LaChapelle, 1955). On Nordbogletscher in south Greenland, Clement (1983[a]) found that the discharge, if any, from the accumulation area was very small.

The sliding during summer, in both the ablation and the accumulation areas, must be caused by changes in the subglacial water pressure brought about by melt-water input from the ablation area to the subglacial water system. As the margin of the glacier is frozen to the bed at the beginning of the melt season (June), the melt water is confined behind cold ice in the ablation area, and water is forced up-glacier through the subglacial water system into the accumulation area. Here, the increased water pressure causes glacier sliding. Finally, the water (in July) breaks through the frozen margin and subglacial water is drained.
In both 1982 (on 8 July) and 1983 (on 21 July) turbid (presumably subglacial) water broke through the glacier at the southern side of the front and drained into stream E2. Although the subglacial water pressure in the vicinity of the outlet drops, melt-water input from ablation may still maintain a high water pressure over most of the ablation area, until ablation decreases or totally stops. Even when the subglacial water pressure in the ablation area decreases, the pressure gradient will still force water up-glacier. This explains the longer period with increased glacier velocity and the later maximum up-glacier.

\section{Vertical displacement}

The vertical positions of the stakes were determined from the fixed points $A_{S}$ and $B_{S}$, and in Figure 4 the results from stake 950 are plotted as movements in the vertical plane, with a six-fold vertical exaggeration. The horizontal velocity at stake 950 and the vertical positions of the fixed point $F$, measured at the same time as the measurements to stake 950 , are also shown.

Apparently, measurements from point $B_{S}$ show an uplift of the glacier surface at the beginning of June, whereas the measurements from point $A_{S}$ show an uplift in the middle of July, at the same time as a sharp rise in horizontal velocity took place. However, it is notable that the measurements from $A_{S}$ to the fixed point $F$ on the opposite side of the glacier also show an apparent "uplift" of the fixed point during the summer months.

It is known that atmospheric refraction varies systematically throughout the day, and Andreasen (1985) found that apparent regular vertical displacements through the day or for a few days were the result of variations in the refraction. In a similar way, the apparent discrepancy between the "uplift" at stake 950 determined from $A_{s}$ and $B_{S}$, respectively, and the apparent uplift of the fixed point $F^{\prime}$ is explained as a result of changes in atmospheric refraction throughout the period.

It is notable that the variations apparently show an annual trend, with low positions (corresponding to a small refraction coefficient) in the spring and in the autumn, and 
high positions (i.e. high refraction coefficient) during the summer. In fact, this is to be expected from the temperature gradients in the near-surface air layer. During the daytime the snow surface is melting and the temperature at the surface is $0^{\circ} \mathrm{C}$. The temperature above the surface is in general higher in the summer than in the spring or autumn, a more positive temperature gradient is found, and a higher refraction coefficient is to be expected.

It is concluded that the apparent uplift of the glacier at stake 950 is not real but is the result of a seasonal change in atmospheric refraction.

\section{CONCLUSIONS}

1. Horizontal velocity shows distinct seasonal variations in both the ablation and the accumulation areas. These variations can only be explained as variations in basa sliding. This, in turn, means that basal ice is at the melting point and that melt water reaches the bed, although the ice and snow temperatures in the ablation and accumulation areas are negative. Melt water from the ablation area is confined behind cold ice and the frozen margin, and water is forced up-glacier through a subglacial water system. The increased basal water pressure causes basal sliding in the accumulation area.

2. Measurements of the vertical displacement show an apparent uplift of the glacier surface. However, the uplift is not real but the result of a seasonal change in atmospheric refraction.

\section{ACKNOWLEDGEMENTS}

I wish to thank P. H. Jensen for valuable help during the field work in Greenland, and R.J. Braithwaite, N.T. Knudsen, O.B. Olesen, and W.H. Theakstone for comments on the manuscript. The field work was carried out with support from the Geological Survey of Greenland, and the Director of the Survey is acknowledged for his permission to publish the results.

\section{REFERENCES}

Andreasen, J.-O. 1982. Overfladehastigheden pá Qamanârssûp sermia 1980-81. Gronlands Geologiske Undersogelse. Gletscher-hydrologiske Meddelelser, Nr. 82/4, p. 27-42.

Andreasen, J.-O. 1985. Apparent short-term glacier velocity variations. Journal of Glaciology, Vol. 31, No. 107, p. 49-53.

Battle, W.R.B. 1951. Glacier movement in north-east Greenland, 1949. Journal of Glaciology, Vol. 1, No. 10, p. 559-63.

Braithwaite, R.J., and Olesen, O.B. 1982. Glaciological investigations at Qamanârssûp sermia. Field report 1979-1981. Gronlands Geologiske Undersogelse. Gletscher-hydrologiske Meddelelser, Nr. 82/2.

Brecher, H.H. 1966. Surface velocity measurements on the Kaskawulsh Glacier, Yukon Territory, Canada. Ohio State University. Institute of Polar Studies, Report, No. 21.

Brzozowski, J., and Hooke, R.L. 1981. Seasonal variations in surface velocity of the lower part of Storglaciären, Kebnekaise, Sweden. Geografiska Annaler, Vol. 63A, Nos. $3-4$, p. $233-40$.

Clement, P. 1983[a]. Glacial-hydrologiske forhold i Nordbosøbassinet, Johan Dahl Land. Gronlands Geologiske Undersøgelse. Gletscher-hydrologiske Meddelelser, Nr. 83/9.

Clement, P. 1983[b]. Glaciologiske undersøgelser i Johan Dahl Land 1982. Gronlands Geologiske Undersogelse. Gletscher-hydrologiske Meddelelser, Nr. 83/1.

Colbeck, S.C., and Gow, A.J. 1974. Isua, Greenland: glaciological investigations during 1973. CRREL Research Report 318.
Friese-Greene, T.W., and Pert, G.J. 1965. Velocity fluctuations of the Bersækerbræ, East Greenland. Journal of Glaciology, Vol. 5, No. 41, p. 739-47.

Henry, T.A., and White, R.J. 1964. The temperature of the Sukkertoppen ice cap (Letter). Journal of Glaciology, Vol. 5, No. 38 , p. 265.

Hodge, S.M. 1974. Variations in the sliding of a temperate glacier. Journal of Glaciology, Vol. 13, No. 69, p. 349-69.

Hooke, R.L., and Koci, B.R. 1978. Temperature measurements on the Barnes Ice Cap, Baffin Island, Canada, and on Sukkertoppen Iskappe, Greenland (Letter). Journal of Glaciology, Vol. 20, No. 83, p. 441-43.

Hooke, R.L., and others. 1983. Seasonal variations in surface velocity, Storglaciären, Sweden, by R.L. Hooke, J. Brzozowski, and C. Bronge. Geografiska Annaler, Vol. 65 A, Nos. $3-4$, p. 263-77.

Iken, A. 1972. Measurements of water pressure in moulins as part of a movement study of the White Glacier, Axel Heiberg Island, Northwest Territories, Canada. Journal of Glaciology, Vol. 11, No. 61, p. 53-58.

Iken, A. [1978.] Variations of surface velocities of some Alpine glaciers measured at intervals of a few hours. Comparison with Arctic glaciers. Zeitschrift für Gletscherkunde und Glazialgeologie, Bd. 13, Ht. 1-2, 1977, p. 23-35.

Iken, A. 1981. The effect of the subglacial water pressure on the sliding velocity of a glacier in an idealized numerical model. Journal of Glaciology, Vol. 27, No. 97, p. 407-21.

Iken, A., and others. The uplift of Unteraargletscher at the beginning of the melt season - a consequence of water storage at the bed?, by A. Iken, H. Röthlisberger, A. Flotron, and W. Haeberli. Journal of Glaciology, Vol. 29, No. 101 , p. 28-47.

LaChapelle, E. 1955. Ablation studies in the Mint Julep area, southwest Greenland. (In Project Mint Julep. Part 2. Maxwell Air Force Base, AL, Arctic, Desert, Tropic Information Center. Research Studies Institute Air University, p. 51-72. (Special Scientific Reports. ADTIC Publication A-104 B.))

Meier, M.F. 1960. Mode of flow of Saskatchewan Glacier, Alberta, Canada. U.S. Geological Survey. Professional Paper 351 .

Müller, F., and Iken, A. 1973. Velocity fluctuations and water regime of Arctic valley glaciers. Union Géodésique et Géophysique Internationale. Association Internationale d'Hydrologie Scientifique. Commission de Neiges et Glaces. Symposium on the Hydrology of Glaciers, Cambridge, 7-13 September 1969, p. 65-82. (Publication No. 95 de l'Association Internationale d'Hydrologie Scientifique.)

Paterson, W.S.B. 1961. Movement of the Sefstrøms Gletscher, north-east Greenland. Journal of Glaciology, Vol. 3, No. 29, p. 845-49.

Paterson, W.S.B. 1964. Variations in velocity of Athabasca Glacier with time. Journal of Glaciology, Vol. 5, No. 39, p. 277-85.

Paterson, W.S.B. 1981. The physics of glaciers. Second edition. Oxford, etc., Pergamon Press. (Pergamon International Library.)

Schimpp, O. 1958. Der Eishaushalt am Hintereisferner in den Jahren 1952/53 und 1953/54. Union Géodésique et Géophysique Internationale. Association Internationale d'Hydrologie Scientifique. Assemblée générale de Toronto, 3-14 sept. 1957. Tom. 4: Neiges et glaces. p. 301-14. (Publication No. 46 de l'Association Internationale d'Hydrologie Scientifique.)

Schytt, V. 1969. Some comments on glacier surges in eastern Svalbard. Canadian Journal of Earth Sciences, Vol. 6, No. 4, Pt. 2, p. 867-73.

Steenstrup, K.J.V. 1883. Bidrag til Kjendskab til Bræerne og Bræ-Isen i Nord-Grønland. Meddelelser om Gronland, Bd. 4, No. 2. 